\title{
Jackal in hide: detection dogs show first success in the quest for golden jackal (Canis aureus) scats
}

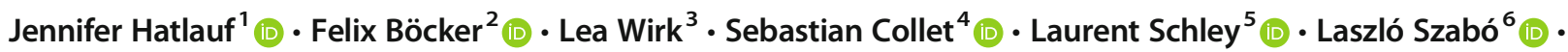 \\ Klaus Hackländer ${ }^{1}$ (1) $\cdot$ Miklós Heltai $^{6}(\mathbb{D}$
}

Received: 13 July 2020 / Accepted: 23 September 2020 / Published online: 7 October 2020

(C) The Author(s) 2020

\begin{abstract}
Golden jackal (Canis aureus) monitoring in central Europe generates more interest and becomes increasingly important with the species' appearance in areas where it was previously unestablished. For genetic monitoring of golden jackals via scat collection, the distinction of jackal scats from those of related species such as the red fox (Vulpes vulpes) is crucial: if done incorrectly, it can falsify diet studies or inflate costs of DNA analyses. In this study, we tested the potential benefits of using domestic dogs to specifically find jackal scats. We used trained scat detection dogs to locate and identify golden jackal scats in an area of dense shrubland, with the species' presence previously confirmed via bioacoustic monitoring. On a total of $133 \mathrm{~km}$ of transects covering at least two golden jackal groups, two human-dog teams found 34 putative golden jackal scats. A total of 26 of these were successfully genetically analysed, of which 19 were attributed to 13 individual golden jackals, an accuracy rate of $73 \%$. Our results show that detection dogs can successfully differentiate golden jackal scats from other species. This tool can be applied to detect golden jackal presence and establish more reliable estimates of group number and size than previously determined through bioacoustic stimulation. By combining both methods, questions about family structures and kinship, seasonal differences in habitat use and territory sizes can be answered. The regular use of detection dogs can present an efficient method to monitor golden jackals on a long-term basis and to learn more about their behaviour and population dynamics.
\end{abstract}

Keywords Scat detection dog $\cdot$ Operant conditioning $\cdot$ DNA $\cdot$ Species differentiation $\cdot$ Bioacoustic monitoring

\section{Introduction}

During the past three decades, golden jackals (Canis aureus moreoticus Geoffroy Saint-Hilaire, 1835) have been expanding within Europe from their core distribution range

Jennifer Hatlauf and Felix Böcker contributed equally to this work.

Communicated by: Rafał Kowalczyk

Electronic supplementary material The online version of this article (https://doi.org/10.1007/s13364-020-00537-4) contains supplementary material, which is available to authorized users.

Jennifer Hatlauf

Jennifer.hatlauf@boku.ac.at

1 Department of Integrative Biology and Biodiversity Research, Institute of Wildlife Biology and Game Management, University of Natural Resources and Life Sciences, Vienna, Austria

2 Forest Research Institute Baden-Württemberg, Wildlife Institute, Freiburg, Germany in the Balkans to areas where they did not occur previously (Arnold et al. 2012; Trouwborst et al. 2015; Krofel et al. 2017). They have been recorded as far to the west as France and as far to the north as Denmark and Finland (Rutkowski et al. 2015; Bouchet 2017; Koistinen 2019). The scientific and
3 LUPUS, German Institute for Wolf Monitoring and Research, Spreewitz, Germany

4 Senckenberg Research Institute, Conservation Genetics, Gelnhausen, Germany

5 Administration de la nature et des forêts, Diekirch, Luxembourg

6 Department of Wildlife Biology, Faculty of Agricultural and Environmental Sciences, Institute for Conservation of Natural Resources, Gödöllö, Hungary 
public interest in this species has increased substantially given various conservation and management issues (Rutkowski et al. 2015; Spassov and Acosta-Pankov 2019). Golden jackals have been mentioned, on the one hand, as an agricultural pest because of possible depredation on small livestock (mainly sheep (Fanin et al. 2018)) and, on the other hand, as a possible pest control, one of their staple preys being rodents (Brooks et al. 1993; Raichev et al. 2013). Moreover, the jackals' flexible diet is sometimes based on anthropogenic resources, like remains from big game hunting left in the forest or from slaughterhouses (Lanszki et al. 2015; Ćirović et al. 2016). Consequently, adaptations in livestock protection, golden jackal management, hunting practices and waste management may be required when considering the presence of this species. The ecology of golden jackals has been poorly studied in Europe, generating problems in the discussions regarding management and conservation of the species (which is listed in Appendix V of the Habitats directive) (Alvares et al. 2019). The growing need for knowledge increases the relevance and necessity of studies into the golden jackal's current distribution and its dispersal and colonization behaviours, and of population monitoring.

For these purposes, different methods have been used, e.g., camera trapping (Pyšková et al. 2016; Farkas et al. 2018), bioacoustic surveys (Giannatos et al. 2005; Krofel 2009; Acosta-Pankov et al. 2018) or population genetics and scat analyses (Rutkowski et al. 2015; Lanszki et al. 2018). For many species, the analysis of fresh scats provides a secure, reliable and non-invasive method to receive genetic information (Frantz et al. 2003; Janečka et al. 2008; DeMatteo et al. 2014). The substantially overlapping food niches of closely related species (Lanszki and Heltai 2010; Akrim et al. 2019; Grimm-Seyfarth et al. 2019) complicate the identification of scats based on morphological criteria (Foran et al. 1997; Baines et al. 2013; Spitzer et al. 2019). In some cases, only DNA analyses can remove doubts about the origin of collected scats. However, genetic analyses are cost-intensive, especially in the case of large sample sizes. To reduce the number of "uncertain" scats and thereby unnecessary costs, researchers started to use the domestic dog's (Canis lupus familiaris) exceptional sense of smell and trained dogs to find and identify samples of interest. The potential of this method has been shown all over the world for a number of species, like maned wolf (Chrysocyon brachyurus), puma (Puma concolor), jaguar (Panthera onca), giant anteater (Myrmecophaga tridactyla) and giant armadillo (Priodontes maximus) (Vynne et al. 2011), kit foxes (Vulpes macrotis mutica) (Smith et al. 2003), free-ranging felids (DeMatteo et al. 2014) or primates (Orkin et al. 2016), including successful distinction between closely related species or even individuals of the same species (Amur tigers (Panthera tigris altaica) (Kerley and Salkina 2007)). In contrast, we assume that humans are not able to distinguish reliably between golden jackal scats and those from closely related canid species, especially in areas of coexistence with the red fox (Vulpes vulpes), a species widespread all over Europe. Moreover, humans have a much smaller overall detection success than dogs (Böcker 2016; Ramsey et al. 2017; Grimm-Seyfarth et al. 2019).

The hypotheses for the present study were (1) that trained detection dogs can reliably find and indicate golden jackal scats and (2) that we can re-confirm individuals over time. Therefore, our corresponding objectives were (1) to test if trained detection dogs could reliably find golden jackal scats in an area of previously confirmed jackal presence, distinguish them from other species and indicate them to humans correctly; (2) to test if through repeated excursions in two consecutive years, it would be possible to re-confirm individuals; (3) to improve overall scat detection success.

\section{Methods}

\section{Study area}

We conducted the present study in November 2018 ("Study Period 1") and March 2019 ("Study Period 2") near the Lake Velence in the administrative division of Fejér, in Hungary (Fig. 1). The elevation in the study area ranges from 140 to $281 \mathrm{~m}$ above sea level (NASA JPL 2013). The maximum snow cover in these areas is $20 \mathrm{~cm}$, the mean precipitation is approximately $525 \mathrm{~mm}$ per year with low variation, and the mean temperature is $1{ }^{\circ} \mathrm{C}$ (Fick and Hijmans 2017). The soil texture is mostly comprised of loam or clay loam. According to the Climate Change Initiative (CCI) landcover dataset, "Herbaceous" (over 35\%) and "Cropland (rainfed)" (over $20 \%$ ) are the two most prominent land-cover types (ESA 2017). Whereas broadleaved trees dominate some of the transects in the northern part of the study area, grassland is more prominent in the southern part. Main crops in both parts are maize, soybeans, rapeseeds and wheat (OneSoil 2018).

With 1354 ha and extensive reed cover, the Ramsar site "Velence and Dinnyés Nature conservation area" represents part of the study area. Bioacoustic surveys and official hunting bag data had previously confirmed the presence of golden jackals in this region (Pallos 2016; Heltai et al. 2018). The rich vertebrate community of the area includes reptiles (e.g., swamp turtle Pseudemydura umbrina and water snakes Natricinae), amphibians (i.e., newts and several frog species), around 300 bird species (35-40 nesting), 21 fish species and mammals (e.g., Eurasian otter Lutra lutra, wild boar Sus scrofa, red deer Cervus elaphus, roe deer Capreolus capreolus, red fox Vulpes vulpes and badger Meles meles). While raccoon dogs (Nyctereutes procyonoides) had never been recorded in the area, stray dogs were occasionally observed (Peter Kiss, personal communication). 
Fig. 1 Study area with the occurring land-cover categories from CORINE (EEA 2020) surrounding transects of both teams for both seasons (dark red line), along with the nine calling stations for the bioacoustic survey (camping sign)

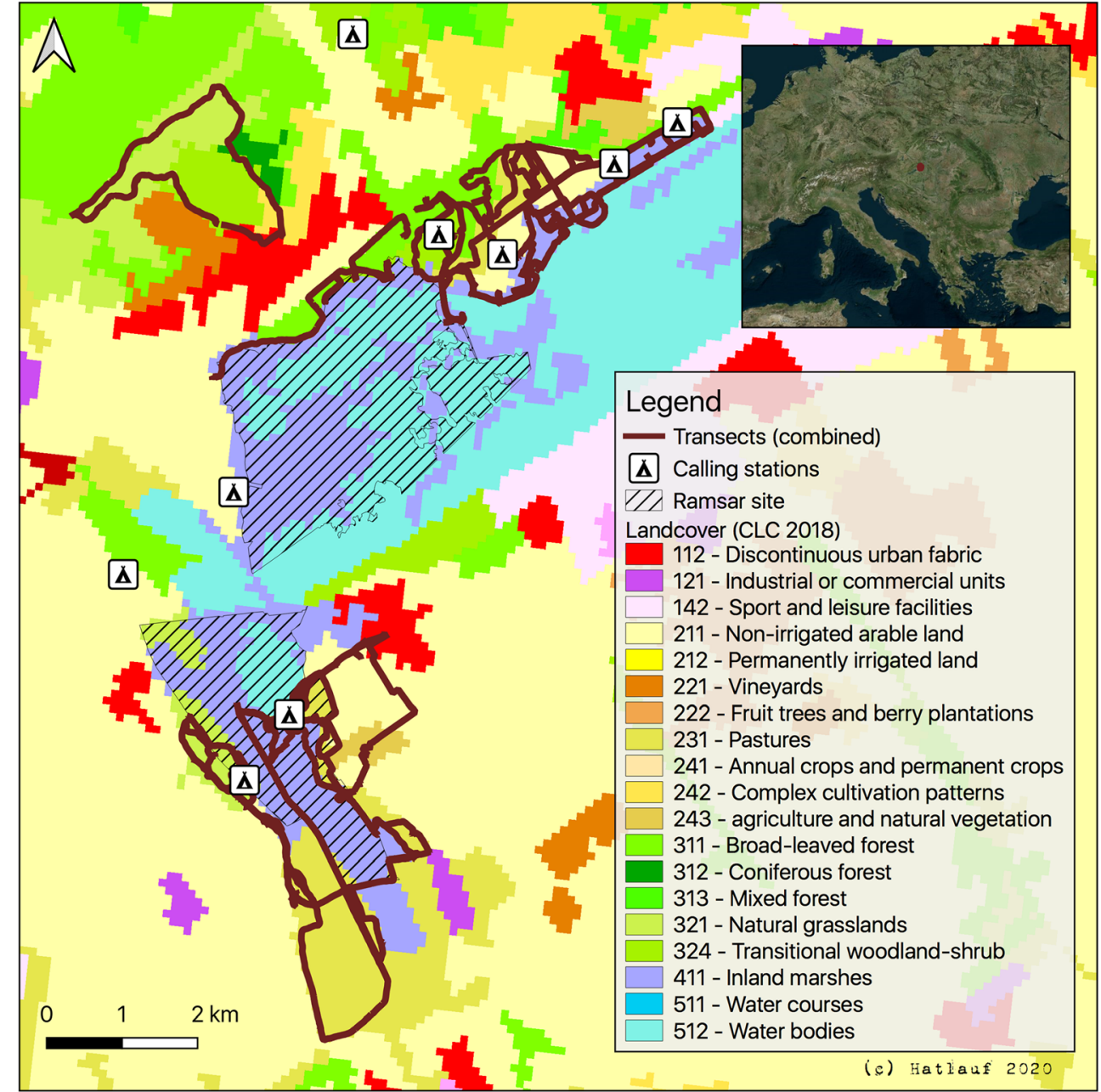

\section{Bioacoustic surveys}

Before the beginning of the scat detection surveys, we investigated the presence of golden jackals in the study area through non-invasive bioacoustic stimulation, a widely used and accepted method (Giannatos et al. 2005; Hatlauf and Hackländer 2016). Acosta-Pankov et al. (2018) showed that jackals respond to howling simulation year-round (with a peak in summer). We played recorded howls at nine randomly selected locations accessible by car (11 calling occasions; Fig. 1) on two consecutive nights in November at the start of Study Period 1 . With a set $1 \mathrm{~km}$ radius surrounding each playback station to account for the assumed human hearing distance (Szabó et al. 2007), the covered area totalled $28.3 \mathrm{~km}^{2}(9 \times$ $3.14 \mathrm{~km}^{2}$ ). While one playback on the second day took place in the morning at 7:00 a.m., all other howling stimulations started approximately $1 \mathrm{~h}$ after sunset in standard weather conditions (windless, without precipitation). Howling tracks (calls) were emitted through a $55-\mathrm{W}$ megaphone (Vexus MEG055). At each calling station, the howling was repeated three times at 4-min intervals. We estimated the number of answering individuals and the direction of answer howls (azimuth). The density was later estimated using two metrics, including the number of groups and individuals per $10 \mathrm{~km}^{2}$.

\section{Dog training}

The trained dogs used in this study were a female Labrador Retriever (born 2007) and a female mix breed German shepherd-Collie-Labrador Retriever (born 2011). Both dogs had previous experience with the detection of wolf (Canis lupus) scats and had been deployed regularly in monitoring activities for several years. For this study, using operant conditioning (Snijders et al. 2019), we trained both dogs over a 12-month period at irregular intervals to detect the smell of golden jackal scats and indicate them to their handlers by barking or sitting. The scats used originated from golden jackals in captivity to ensure that the training sessions only included unequivocal faeces of the target species. Samples from 15 individuals of both sexes and different age classes were available. The training samples were stored frozen in glass jars at $-18{ }^{\circ} \mathrm{C}$ and thawed specifically for training. Since decomposition processes and weather influence samples in the wild and therefore the scent of the target species, 
the training samples were also exposed to different weather conditions (e.g., sun and rain) and used at different decomposition levels. This was done to offer the dogs the odour of the target species in as many ways as possible. After the first basic conditioning, scats of non-target species were presented to the dogs in addition to the target smell to achieve a distinction between enticing odours and the scent of the target species. During training, we tried to simulate the expected situation in the field as realistically as possible, including outdoor training in similar landscapes. Regular repetitions of the basic training took place continuously, and before each deployment in the field (Study Periods 1 and 2), training was intensified.

\section{Scat sampling}

We selected possible transects for the two human-dog teams (one team: dog and its handler) based on digital map material (Fig. 1). Due to their previous experience in wolf monitoring, the dogs were used to work in the field for long periods. Each dog handler had the freedom to assess the dog and its condition and motivation at any given time, structuring the search accordingly. A detailed timetable for fieldwork ensured that the dogs could rest after the journey to the study site and before the start of each active survey. The transects were flexibly adapted to the circumstances during the search if required (for example, non-accessible paths). The dogs were kept on long leashes. We covered the study area as completely as possible. Teams restricted their movements along paths or path-like structures such as wood strips or mowed aisles in the reedbeds.

We gathered scat samples during both study periods. The samples were collected exclusively based on the indication given by the two dogs and recorded geographic coordinates using field GPS devices (Garmin eTrex series). Wearing disposable rubber gloves to avoid cross-contamination, we photographed and measured the scats and collected fingernail-sized samples for genetic analysis, preserved in $96 \%$ ethanol. The scats were stored in commercial freezer bags at $-15^{\circ} \mathrm{C}$.

\section{Genetic analysis}

DNA from scats was extracted using the QIAamp DNA Fast Stool Kit (Qiagen, Hilden, Germany) following the manufacturer's instructions. For genetic identification of species, sex and individual, microsatellite fragment and mitochondrial sequence analysis was applied.

For initial species identification on samples collected in 2018, we performed sequence analysis with primers L15995 (Taberlet and Bouvet 1994) and H16498 (Fumagalli et al. 1996). Samples from 2019 were analysed with primers L15995 and WdloopH (Caniglia et al. 2013) as well as primers WdloopL (Caniglia et al. 2013) and WdloopH specific for detecting the genus Canis. Sequences were compared with the NCBI GenBank via BLAST search. While sequence length varies with primers and species, all used primer pairs cover the same hypervariable domain of the mitochondrial control region (D-loop) (Pun et al. 2009).

In confirmed golden jackal samples, we amplified 13 unlinked autosomal microsatellite loci as well as two sex markers that are regularly used for genetic analyses in wolves and domestic dogs (Canis lupus): CPH5 (Fredholm and Winterø 1995); FH2001, FH2010, FH2017, FH2054, FH2087, FH2088, FH2097, FH2137, FH2140 and FH2161 (Francisco et al. 1996); vWF (Shibuya et al. 1994); PEZ17 (Neff et al. 1999); DBX6 and DBY7 (Seddon 2005). The use of markers that are cross-amplifying among canid species such as wolves and dogs is widespread in genetic studies on golden jackals (Zachos et al. 2009; Fabbri et al. 2013; Rutkowski et al. 2015; Stronen et al. 2020). All markers were previously tested on golden jackal samples obtained from dead animals from Germany, Denmark and Hungary as well as scats from German/Danish wildlife monitoring.

Three multiplex PCRs were performed in $10-\mu$ l reactions containing HotStarTaq Master Mix (Qiagen), $0.2 \mu \mathrm{M}$ of each primer, 2 ng BSA and genomic DNA. PCRs were run in a T1 plus Thermocycler (Analytik Jena, Germany) with an initial denaturation step of $95^{\circ} \mathrm{C}$ for $3 \mathrm{~min}$ followed by 5 cycles of $94{ }^{\circ} \mathrm{C}$ for $30 \mathrm{~s}, 60^{\circ} \mathrm{C}$ for $90 \mathrm{~s}$ and $72{ }^{\circ} \mathrm{C}$ for $60 \mathrm{~s}$; another 5 cycles of $94{ }^{\circ} \mathrm{C}$ for $30 \mathrm{~s}, 58^{\circ} \mathrm{C}$ for $90 \mathrm{~s}$ and $72^{\circ} \mathrm{C}$ for $60 \mathrm{~s}$; 5 cycles of $94{ }^{\circ} \mathrm{C}$ for $30 \mathrm{~s}, 54^{\circ} \mathrm{C}$ for $90 \mathrm{~s}$ and $72{ }^{\circ} \mathrm{C}$ for $60 \mathrm{~s}$; 20 cycles of $94^{\circ} \mathrm{C}$ for $30 \mathrm{~s}, 54^{\circ} \mathrm{C}$ for $90 \mathrm{~s}$ and $72{ }^{\circ} \mathrm{C}$ for $60 \mathrm{~s}$; and a final extension of $72{ }^{\circ} \mathrm{C}$ for $30 \mathrm{~min}$. PCR products were electrophoresed on an ABI3730 DNA Analyzer (Life Technologies GmbH, Darmstadt, Germany) and fragment sizes were determined using GeneMarker v1.90 (Softgenetics LLC, State College, Pennsylvania) by comparison to LIZ600 as an internal size standard. Every multiplex was replicated four times to account for genotyping errors (Navidi et al. 1992; Taberlet et al. 1999).

\section{Density estimates based on scats and detection accuracy}

Based on scats found, relative abundance of golden jackals was expressed according to the general faecal density index (FDI) values (described in Webbon et al. 2004). We calculated the mean number of faecal encounters per kilometre as an indicator for the FDI based solely on golden jackal scats discovered by the human-dog teams and positively confirmed by the genetic analysis.

For calculating the detection accuracy, we defined "unidentifiable" samples, without amplifiable DNA information, and "incorrect" samples, from non-target species. The detection accuracy of the dogs was the calculated proportion of scat samples from which golden jackal DNA could be identified 
relative to the total number of samples that had amplifiable DNA.

The results from the field sampling and the scat details were summarized and analysed in R (Version 3.6.1; R Core Team 2019). The GPS positions from the scats found and the results from bioacoustic monitoring were combined on a map with the GIS software QGIS version 3.8 (QGIS Development Team 2019). After pooling positive results from DNA analysis and bioacoustic stimulation, the counts of records within the 1-km pixel grid (Fig. 2) was calculated through the "Count Points in Polygon" function in the "Vector Analysis" tools.

\section{Results}

\section{Jackal presence confirmation}

Through bioacoustic stimulation, we reaffirmed golden jackal presence in our study area: we received replies on five out of 11 occasions: one single answer and four answers by more than two individuals, resulting in an overall response rate of $45 \%$. According to these bioacoustic findings, we estimated at least two territorial golden jackal groups within the sampled area, corresponding to a density of 0.7 groups per $10 \mathrm{~km}^{2}$. Based on the assumptions that mean group size is $4-5$ individuals and that one acoustic survey point covers an area with the radius of $1 \mathrm{~km}$ (Szabó et al. 2007), there were 8-10 individuals in the surveyed area, corresponding to a density of $2.8-3.5$ individuals per $10 \mathrm{~km}^{2}$.

\section{Scat detection accuracy and DNA results}

During the two study periods, the two human-dog teams searched a total length of transects of $133.03 \mathrm{~km}$ and found 34 putative golden jackal scats (Table 1; example pictures and data of scats in the Online Resource 1). Almost $30 \%$ of scats were found on path edges in raised positions, almost $30 \%$ in the middle of the path (in non-raised positions), and the remaining samples on path edges, in the driving lane or off the paths (Online Resource 1). Of the 34 scats, 31 could be used for genetic analysis, the other three being in too bad condition. Species identification was successful for 26 samples, with 19 being attributed to golden jackals. For five samples, species identification was unsuccessful due to either low DNA quality or quantity (Table 2). Genotyping identified a total of 13 different individuals ( 8 males, 5 females). Three of them were sampled twice, and for two samples, genotyping did not yield a result (Table 3). Detection accuracy from the 26 amplifiable samples was therefore $73 \%$.

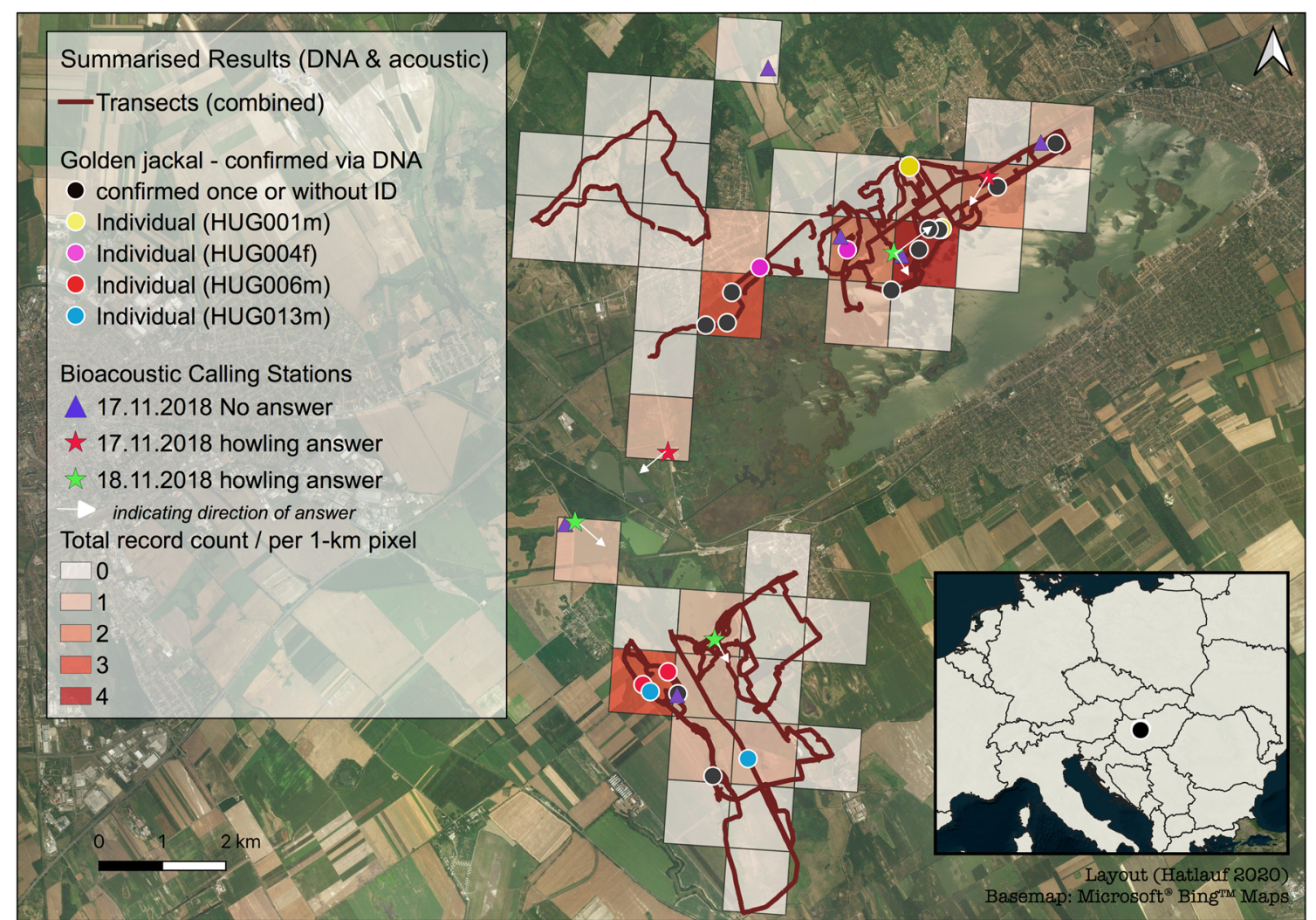

Fig. 2 Combined results in the surveyed area. The dots show confirmed positive golden jackal scats via DNA confirmation, and the red line is representing the walked transects; stars and triangles refer to the answers within bioacoustic monitoring. The coloration of the grid cells indicates the count of positive golden jackal records within given $1-\mathrm{km}$ pixel 
Table 1 Samples found by the two human-dog teams (four excursions per team per Study Period).

\begin{tabular}{|c|c|c|c|c|c|c|c|c|}
\hline & \multirow[t]{2}{*}{ Study period } & \multicolumn{2}{|c|}{ Distance walked $(\mathrm{km})$} & \multicolumn{2}{|c|}{ Duration (min) } & \multicolumn{2}{|c|}{$\begin{array}{l}\text { Confirmed golden } \\
\text { jackal scats }\end{array}$} & \multirow{2}{*}{$\begin{array}{l}\text { Confirmed golden jackal } \\
\text { scats per km (FDI) } \\
\text { Both teams }\end{array}$} \\
\hline & & team 1 & team 2 & team 1 & team 2 & team 1 & team 2 & \\
\hline \multirow[t]{2}{*}{ Min. (per excursion) } & 1 & 6.50 & 5.00 & 130 & 120 & 0 & 0 & 0 \\
\hline & 2 & 5.00 & 2.29 & 60 & 50 & 0 & 0 & 0 \\
\hline \multirow[t]{2}{*}{ Max. (per excursion) } & 1 & 12.50 & 9.00 & 270 & 240 & 2 & 2 & 0.40 \\
\hline & 2 & 13.00 & 10.90 & 300 & 270 & 4 & 3 & 0.34 \\
\hline \multirow[t]{2}{*}{ Total (all transects) } & 1 & 39.10 & 26.40 & 625 & 780 & 2 & 6 & 0.12 \\
\hline & 2 & 35.62 & 31.91 & 870 & 710 & 5 & 6 & 0.16 \\
\hline \multirow[t]{2}{*}{ Mean (per excursion) } & 1 & 9.78 & 6.60 & 208 & 195 & 0.5 & 1.5 & 0.015 \\
\hline & 2 & 8.90 & 7.98 & 217 & 178 & 1.25 & 1.5 & 0.02 \\
\hline
\end{tabular}

In terms of work effort, one jackal howling response required approximately $1 \mathrm{~h}$ of bioacoustic monitoring, whereas $7 \mathrm{~km}$ of transect ( $2.88 \mathrm{~h}$ of field work) were needed to collect one jackal scat.

\section{Scat density and summary}

For both study periods combined, the FDI was 0.14 golden jackal scats per km (summarized findings in Fig. 2). The FDI was 0.12 and 0.16 scats per km for Study Period 1 and Study Period 2, respectively. The individual FDI (based on DNA confirmed individuals) resulted in 0.1 different individuals per km.

\section{Discussion and conclusion}

Scats have been used in a number of well-known and universal methodologies for a variety of species and with various specific non-invasive monitoring objectives (Foran et al. 1997; Delahay et al. 2001; Baines et al. 2013; Ramsey et al. 2017). In our study, detection dogs successfully found and indicated golden jackal scats with an accuracy of $73 \%$. These results indicate that it is possible to overcome the uncertainty of distinguishing between scats from foxes, golden jackals and other species. Detection accuracy can vary between dogs, study areas and study periods and ranged from 60 to $100 \%$ in other studies (Smith et al. 2003; Wasser et al. 2004; MacKay et al. 2008; Orkin et al. 2016). Our results support the first hypothesis that detection dogs can distinguish between species with an assumingly great overlap in food niche and habitat, like golden jackals and red foxes (Lanszki et al. 2006; Lanszki et al. 2016; Vlasseva et al. 2017), with a relatively high accuracy even in this first trial. We were not able to draw any meaningful conclusions regarding our second hypothesis (residency within the study area between the two sampling occasions) as the scat of only one individual (a female) was detected during both study periods. This might indicate a high turnover in the jackal population of the study area, which may be partly driven by hunting (shot individuals: $n=9$ (2016), $n=10$ (2017), $n=1$ (2018), $n=12$ (2019) (Peter Kiss and Zoltan Kovacs personal communications)). Other reasons for the low re-detection rate may include home-range sizes extending beyond the study area, seasonal changes of home-ranges or the inclusion of dispersing individuals in our sample.

\section{Dog training and practical experiences}

To our knowledge, this is the first time that detection dogs were trained to locate and identify golden jackal scats in the
Table 2 Results of successful genetic species identification for 26 scat samples

\begin{tabular}{lllll}
\hline \multirow{2}{*}{ Species } & \multicolumn{2}{l}{ Number of samples } & & \multirow{2}{*}{ Percentage (\%) } \\
\cline { 2 - 5 } & Study Period 1 & Study Period 2 & Total & \\
\hline Canis aureus & 8 & 11 & 19 & 73.1 \\
Canis familiaris & - & 3 & 3 & 11.5 \\
Vulpes vulpes & 2 & 1 & 3 & 11.5 \\
Lutra lutra & 1 & - & 1 & 3.9 \\
Total & 11 & 15 & 26 & \\
\hline
\end{tabular}


Table 3 List of the 13 genetically identified individuals. Italic indicates the individual that was sampled over two study periods $(m$ male, $f$ female, $N A$ not available). Locations of recurring individuals are shown in Fig. 2

\begin{tabular}{|c|c|c|}
\hline \multirow[t]{2}{*}{ Individual name } & \multicolumn{2}{|c|}{ Study periods } \\
\hline & 1 & 2 \\
\hline HUG001m ${ }^{\mathrm{a}}$ & 2 & 0 \\
\hline HUG002m & 1 & 0 \\
\hline HUG003f & 1 & 0 \\
\hline$H U G 004 f$ & 1 & 1 \\
\hline HUG005f & 1 & 0 \\
\hline HUG006m ${ }^{a}$ & 2 & 0 \\
\hline HUG007m & 0 & 1 \\
\hline HUG008m & 0 & 1 \\
\hline HUG009m & 0 & 1 \\
\hline HUG010f & 0 & 1 \\
\hline HUG011m & 0 & 1 \\
\hline HUG012f & 0 & 1 \\
\hline HUG013m ${ }^{a}$ & 0 & 2 \\
\hline NA & 0 & 2 \\
\hline
\end{tabular}

${ }^{a}$ Sampled twice within one study period

wild. This study was also the first practical experience in the search for golden jackal scats for the two dogs and their handlers. During the indication of some scats in Study Period 1, both handlers described an uncertain behaviour of the dogs not observed in training situations. Therefore, more experience in fieldwork could increase the success rate (as experienced by Orkin et al. 2016), which might already be indicated by the higher FDI during the Study Period 2 (0.16 versus 0.12 in the first Study Period). Nevertheless, this slight increase in FDI could have been coincidental or the result of other previously mentioned possible influences like hunting pressure or changing home ranges.

Besides highly degraded scats (consequently without a genetic result), we also analysed several samples where dogs displayed a rather ambiguous indicating behaviour during the encounter. Genetic analysis identified some of those samples as red fox (twice), domestic dog (twice) and otter (once). Due to the ability of the handlers to assess the behaviour of the dogs in unsure situations, this additional information should enable the handlers to interpret indications more efficiently in the future, thus improving detection accuracy. Nevertheless, there can be other reasons for false detections, namely golden jackals marking the scat of a non-target species with urine (leading to detection by the dog, collection and inclusion in the genetic analysis of a nontarget scat) (DeMatteo et al. 2018). From our results, it seems that dogs and handlers need more practice in fieldwork situations with a novel target scent in order to increase accuracy.

\section{Density and future research}

Besides the overlap between acoustic stimulation and scat findings, the results indicate that a combination of these two methods can increase knowledge about distribution and population dynamics of golden jackals. Some of the jackal scats were registered in areas without answers to acoustic stimulation. Likewise, locations of howls did not always yield scat findings in the vicinity.

While producing one golden jackal sample per $7 \mathrm{~km}$ or $2.88 \mathrm{~h}$ of fieldwork, the work effort by the human-dog teams was relatively high compared with bioacoustic surveys, where $1 \mathrm{~h}$ per positive answer was required. Nevertheless, scat collection and analysis have clear benefits, like providing certainty regarding species, sex and number of individuals. It can also help to assess the marking behaviour of jackals, hardly studied thus far, in more detail in the future. During our investigation, we found several scats on path edges or off the paths (see Online Resource 1). The detection dogs thus discovered and identified hidden off-path scats that are hard to find for humans. Despite the great advantage that genetic analyses can determine species, sex and individuals, they are cost-intensive. Therefore, preselecting the samples with the help of detection dogs will minimize unnecessary costs and is therefore highly recommendable. The use of human-dog teams itself can be arranged in a cost-efficient way (Orkin et al. 2016). Considering the recurring difficulties for humans to correctly distinguish scats based on morphology, even from species differing as much in body size and diet as wolves and red foxes (Reinhardt et al. 2015), only the help of detection dogs may actually guarantee more efficiency in non-invasive studies on canids based on scats. If the only objective is to confirm golden jackal presence in an area, the sole use of bioacoustic stimulation is still the most efficient and cost-effective method. By choosing an integrated approach combining the help of detection dogs to find jackal scats with bioacoustic surveys at the beginning of fieldwork, one can more effectively investigate aspects of jackal biology and ecology, such as diet, habitat use, territory size, family structures and kinship and hormone balance. The regular use of detection dogs therefore provides an efficient method to monitor golden jackals on a long-term basis and to learn more about their behaviour and population dynamics on a local as well as a regional scale.

Acknowledgements We thank the Senckenberg Research Institute for administering the samples and are very grateful for the supportive cooperation with the Danube-Ipoly National Park Directorate administration of Lake Velence. We thank Hans Acs, Johannes and Carmen Lukasser, Emanuel Liechtenstein, the Budakeszi Wildlife Park and all the zoo keepers that supported this study and kindly supplied us with fresh golden jackal scats for the dog training. We are grateful to Brady Mattsson for improving the manuscript.

Authors' contributions JH and FB conceptualized the study. JH, FB, LW and $\mathrm{KH}$ wrote the manuscript, with input from SC and LSC. JH analysed and visualized the data. FB and LW trained the detection dogs and conducted bioacoustic fieldwork together with LSZ and JH. SC carried out the DNA analysis. MH and LSZ organized the logistics in, and provided the description of, the study area. All authors reviewed the manuscript. 
Funding Open access funding provided by University of Natural Resources and Life Sciences Vienna (BOKU). This study was partially funded by the OEAD and OMAA (98öu10). JH is a recipient of the DOC Fellowship of the Austrian Academy of Sciences at the Institute of Wildlife Biology and Game Management, University of Natural Resources and Life Sciences. The publication is supported by the EFOP-3.6.3-VEKOP-16-2017-00008 project. MH and LSZ are cofinanced by the European Union and the European Social Fund. Open access funding provided by the University of Natural Resources and Life Sciences Vienna (BOKU).

Data availability The datasets analysed during the current study are available from the corresponding author on reasonable request. The source dataset of land cover (CORINE) analysed during the current study is available at the following location: https://land.copernicus.eu/paneuropean/corine-land-cover/clc2018

\section{Compliance with ethical standards}

Conflict of interest The authors declare that they have no conflict of interest.

\section{Ethics approval Not applicable.}

Open Access This article is licensed under a Creative Commons Attribution 4.0 International License, which permits use, sharing, adaptation, distribution and reproduction in any medium or format, as long as you give appropriate credit to the original author(s) and the source, provide a link to the Creative Commons licence, and indicate if changes were made. The images or other third party material in this article are included in the article's Creative Commons licence, unless indicated otherwise in a credit line to the material. If material is not included in the article's Creative Commons licence and your intended use is not permitted by statutory regulation or exceeds the permitted use, you will need to obtain permission directly from the copyright holder. To view a copy of this licence, visit http://creativecommons.org/licenses/by/4.0/.

\section{References}

Acosta-Pankov I, Spassov N, Banea OC (2018) Seasonal differences in howling response of golden jackals Canis aureus L., 1758 (Mammalia: Canidae) in eastern Bulgaria. Acta Zoologica Bulgarica 70(4):539-545

Akrim F, Mahmood T, Nadeem MS, Dhendup T, Fatima H, Andleeb S (2019) Diet composition and niche overlap of two sympatric carnivores: Asiatic jackal Canis aureus and Kashmir hill fox Vulpes vulpes griffithii, inhabiting Pir Lasura National Park, northeastern Himalayan region, Pakistan. Wildl Biol 2019(1):1-9. https://doi. org/10.2981/wlb.00440

Alvares F, Bogdanowicz W, Campbell LAD, Godinho R, Hatlauf J, Jhala YV, Kitchener A, Koepfli K, Krofel M, Senn H, Sillero-Zubiri C, Viranta S, Werhahn G (2019) Old World Canis spp. with taxonomic ambiguity: workshop conclusions and recommendations CIBIO, Vairão, Portugal, May 2019, 1-8 https://www.canids.org/CBC/ Old_World_Canis_Taxonomy_Workshop.pdf. Accessed 10 Mar 2020

Arnold J, Humer A, Heltai M, Murariu D, Spassov N, Hackländer K (2012) Current status and distribution of golden jackals Canis aureus in Europe. Mammal Rev 42(1):1-11

Baines D, Aebischer N, Macleod A, Woods J (2013) Pine marten Martes martes and red fox Vulpes vulpes sign indices in Scottish forests: population change and reliability of field identification of scats. Wildl Biol 19(4):490-495

Böcker F (2016) Sign survey, camera trapping, scent detection dog evaluation of different methods to investigate wolf presence. Master's thesis, Albert-Ludwigs-University Freiburg im Breisgau

Bouchet St (2017) Le chacal doré observé pour la première fois en France. Le dauphiné https://www.ledauphine.com/insolite/2017/ 12/14/le-chacal-dore-observe-pour-la-premiere-fois-en-france. Accessed 11 June 2020

Brooks JE, Haque ME, Ahmad S (1993) Status of the golden jackal as an agricultural pest in Bangladesh: Joe E. Brooks, with M. Emdadul Haque and colleagues, discusses the jackal's role in the agroecosystem. Crop Prot 12(8):563-564

Caniglia R, Fabbri E, Mastrogiuseppe L, Randi E (2013) Who is who? Identification of livestock predators using forensic genetic approaches. Forensic Sci Int Genet 7:397-404

Ćirović D, Penezić A, Krofel M (2016) Jackals as cleaners: ecosystem services provided by a mesocarnivore in human-dominated landscapes. Biol Conserv 199:51-55. https://doi.org/10.1016/j.biocon. 2016.04.027

Delahay RJ, Brown JA, Mallinson PJ, Spyvee PD, Handoll D, Rogers LM, Cheeseman CL (2001) The use of marked bait in studies of the territorial organization of the European Badger (Meles meles). Mammal Rev 30(2):73-87

DeMatteo KE, Rinas MA, Argüelles CF, Holmann BE, Di Bitetti MS, Davenport B, Parker PG, Eggert LS (2014) Using detection dogs and genetic analyses of scat to expand knowledge and assist felid conservation in Misiones, Argentina. Integr Zool 9:623-639

DeMatteo KE, Blake LW, Young JK, Davenport B (2018) How behavior of nontarget species affects perceived accuracy of scat detection dog surveys. Sci Rep 8:13830. https://doi.org/10.1038/s41598-01832244-1

EEA (2020) CORINE land cover 2018, version 2020_20u1. Copernicus Land Monitoring Service. https://land.copernicus.eu/pan-european/ corine-land-cover/clc2018. Accessed 29 Apr 2020

ESA (2017) Land cover CCI product user guide version 2. Tech Rep http://maps.elie.ucl.ac.be/CCI/viewer/download/ESACCI-LC-Ph2PUGv2_2.0.pdf. Accessed 29 Apr 2020

Fabbri E, Caniglia R, Galov A, Arbanasić H, Lapini L, Bošković I, Florijančić T, Vlasseva A, Ahmed A, Mirchev R, Randi E (2013) Genetic structure and expansion of golden jackals (Canis aureus) in the north-western distribution range (Croatia and eastern Italian Alps). Conserv Genet 15:187-199. https://doi.org/10.1007/ s10592-013-0530-7

Fanin Y, Pesaro ST, Filacorda ST, Pieri M (2018) Golden jackal (Canis aureus moreoticus Geoffroy, 1835) predatory behaviour and carcass consumption of livestock in North East Italy. In: Giannatos G, Banea OC, Hatlauf J, Sillero-Zubiri C, Georgiadis CA, Legakis (eds) Proceedings of the 2nd International Jackal Symposium, Marathon Bay, Attiki Greece 2018. Hell. Zool. Arch., 9 Nov 2018, ISSN: 1106-2134, 93

Farkas A, Jánoska F, Náhlik A (2018) Ecological niche relationships in golden jackal's core area of distribution in early stages of cub rearing season. Proceedings of the Biennial International Symposium "Forest and Sustainable Development" Brașov, Romania. 25th27th of October 2018:211-222

Fick SE, Hijmans RJ (2017) WorldClim 2: new 1-km spatial resolution climate surfaces for global land areas. Int J Climatol 37(12):43024315

Foran DR, Crooks KR, Minta SC (1997) Species identification from scat: an unambiguous genetic method. Wildl Soc Bull 25(4):835-839

Francisco LV, Langsten AA, Mellersh CS, Neal CL, Ostrander EA (1996) A class of highly polymorphic tetranucleotide repeats for canine genetic mapping. Mamm Genome 7(5):359-362

Frantz AC, Pope LC, Carpenter PJ, Roper TJ, Wilson GJ, Delahay RJ, Burke T (2003) Reliable microsatellite genotyping of the Eurasian 
badger (Meles meles) using faecal DNA. Mol Ecol 12(6):16491661

Fredholm M, Winterø AK (1995) Variation of short tandem repeats within and between species belonging to the Canidae family. Mamm Genome 6(1):11-18

Fumagalli L, Taberlet P, Favre L, Hausser J (1996) Origin and evolution of homologous repeated sequences in the mitochondrial DNA control region of shrews. Mol Biol Evol 13(1):31-46

Giannatos G, Marinos Y, Maragou P, Catsadora- kis G (2005) The status of the golden jackal (Canis aureus L.) in Greece. Belg J Zool 135(2): $145-149$

Grimm-Seyfarth A, Zarzycka A, Nitz T, Heynig L, Weissheimer N, Lampa S, Klenke R (2019) Performance of detection dogs and visual searches for scat detection and discrimination amongst related species with identical diets. Nat Conserv 37:81-98

Hatlauf J, Hackländer K (2016) Preliminary results for golden jackal (Canis aureus) survey in Austria. Beiträge zur Jagd- und Wildtierforschung 41:295-306

Heltai M, Pallos Z, Szabó L, Márton M, Lanszki J (2018) Golden jackal population dynamics in certain study areas of Hungary - examples for hectic population change and invasion. Elleniko Zoologiko Arheio [Hell Zool Arch] 2018(9):47-47

Janečka JE, Jackson R, Yuquang Z, Diqiang L, Munkhtsog B, BuckleyBeason V, Murphy WJ (2008) Population monitoring of snow leopards using noninvasive collection of scat samples: a pilot study. Anim Conserv 11(5):401-411

Kerley LL, Salkina GP (2007) Using scent-matching dogs to identify individual Amur tigers from scats. J Wildl Manag 71(4):1349-1356

Koistinen A (2019) Tutkija vahvistaa: Suomen ensimmäinen sakaalihavainto Rautavaaralla - yksilö on todennäköisesti sama, joka oli Enossa - kuvat https://www.karjalainen.fi/uutiset/uutisalueet/kotimaa/item/224551. Accessed 19 Jan 2020

Krofel M, Giannatos G, Ćirović D, Stoyanov S, Newsome TM (2017) Golden jackal expansion in Europe: a case of mesopredator release triggered by continent-wide wolf persecution? Hystrix 28(1):9-15

Krofel M (2009) Confirmed presence of territorial groups of golden jackals (Canis aureus) in Slovenia. Natura Sloveniae 11(1): 65-68

Lanszki J, Heltai M (2010) Food preferences of golden jackals and sympatric red foxes in European temperate climate agricultural area (Hungary). Mammalia 74(3):267-273. https://doi.org/10.1515/ MAMM.2010.005

Lanszki J, Heltai M, Szabó L (2006) Feeding habits and trophic niche overlap between sympatric golden jackal (Canis aureus) and red fox (Vulpes vulpes) in the Pannonian ecoregion (Hungary). Can J Zool 84:1647-1656

Lanszki J, Kurys A, Ács K, Heltai M, Csányi S (2015) Diet composition of the golden jackal in an area of intensive big game management. Ann Zool Fenn 52(4):243-255. https://doi.org/10.5735/086.052. 0403

Lanszki J, Kurys A, Szabó L, Nagyapáti N, Porter LB, Heltai M (2016) Diet composition of the golden jackal and the sympatric red fox in an agricultural area (Hungary). Folia Zool 65(4):310-322

Lanszki J, Hayward MW, Nagyapáti N (2018) Feeding responses of the golden jackal after reduction of anthropogenic food subsidies. PLoS One 13(12):e0208727

MacKay P, Smith DA, Long RA, Parker M (2008) Scat detection dogs. In: Long et al (eds) Noninvasive survey methods for carnivores. Island Press, Washington, pp 183-222

NASA JPL (2013) NASA shuttle radar topography Mission Global 1 arc second [SRTMGL1 v003]. EOSDIS Land Processes DAAC. https:// doi.org/10.5067/MEaSUREs/SRTM/SRTMGL1.003. Accessed 29 Apr 2020

Navidi W, Arnheim N, Waterman MS (1992) A multiple-tubes approach for accurate genotyping of very small DNA samples by using PCR: statistical considerations. Am J Hum Genet 50(2):347-359
Neff MW, Broman KW, Mellersh CS, Ray K, Acland GM, Aguirre GD, Ziegle JS, Ostrander EA, Rine J (1999) A second-generation genetic linkage map of the domestic dog, Canis familiaris. Genetics 151(2): $803-820$

OneSoil (2018) Hungary, Transdanubia https://map.onesoil.ai/2018/hu/ transdanubia\#11.25/47.1903/18.562. Accessed 29 Apr 2020

Orkin JD, Yang Y, Yang C, Douglas WY, Jiang X (2016) Cost-effective scat-detection dogs: unleashing a powerful new tool for international mammalian conservation biology. Sci Rep 6:34758. https://doi.org/ $10.1038 /$ srep34758

Pallos Z (2016) A Velencei-tavi aranysakál populáció jelenlegi helyzete. http://volgy-hid.blogspot.com/2016/02/a-velencei-taviaranysakalokrol.html. Accessed 23 Apr 2020

Pun KM, Albrecht C, Castella V, Fumagalli L (2009) Species identification in mammals from mixed biological samples based on mitochondrial DNA control region length polymorphism. Electrophoresis 30: 1008-1014

Pyšková K, Storch D, Horáček I, Kauzál O, Pyšek P (2016) Golden jackal (Canis aureus) in the Czech Republic: the first record of a live animal and its long-term persistence in the colonized habitat. ZooKeys 641:151-163

QGIS Development Team (2019) QGIS geographic information system. Open Source Geospatial Foundation. http:/qgis.org. Downloaded 11 August 2019

R Core Team (2019) R: a language and environment for statistical computing. R Foundation for Statistical Computing, Vienna, Austria. https://www.R-project.org. Downloaded 10 December 2019

Ramsey DSL, Barclay C, Campbell CD, Dewar E, MacDonald AJ, Modave E, Quasim S, Sarre SD (2017) Detecting rare carnivores using scats: implications for monitoring a fox incursion into Tasmania. Ecol Evol 8(1):732-743. https://doi.org/10.1002/ece3. 3694

Reinhardt I, Kaczensky P, Knauer F, Rauer G, Kluth G, Wölfl S, Huckschlag D, Wotschikowsky U (2015) Monitoring von Wolf, Luchs und Bär in Deutschland. Bundesamt für Naturschutz, Deutschland. BfN-Skripten 413

Rutkowski R, Krofel M, Giannatos G, Ćirović D, Männil P, Volokh AM, Lanszki J, Heltai M, Szabó L, Banea OC, Yavruyan E, Hayrapetyan V, Kopaliani N, Miliou A, Tryfonopoulos GA, Lymberakis P, Penezić A, Pakeltyte G, Suchecka E, Bogdanowicz W (2015) A European concern? Genetic structure and expansion of golden jackals (Canis aureus) in Europe and the Caucasus. PLoS One 10(11):e0141236. https://doi.org/10.1371/journal.pone.0141236

Raichev EG, Tsunoda H, Newman C, Masuda R, Georgiev DM, Kaneko Y (2013) The reliance of the golden jackal (Canis aureus) on anthropogenic foods in winter in central Bulgaria. Mammal Study 38(1):19-27

Seddon JM (2005) Canid-specific primers for molecular sexing using tissue or non-invasive samples. Conserv Genet 6:147-149

Shibuya H, Collins BK, Huang TH-M, Johnson and GS (1994) A polymorphic (AGGAAT)n tandem repeat in an intron of the canine von Willebrand factor gene. Anim Genet 25(2): 122

Smith DA, Ralls K, Hurt A, Adams B, Parker M, Davenport B, Smith MC, Maldonado JE (2003) Detection and accuracy rates of dog trained to find scats of San Joaquin kit foxes (Vulpes macrotis mutica). Anim Conserv 6(4):339-346

Snijders L, Greggor AL, Hilderink F, Doran C (2019). Effectiveness of animal conditioning interventions in reducing human-wildlife conflict: a systematic map protocol. Environ Evid 2019, 8(Suppl 1):10. https://doi.org/10.1186/s13750-019-0153-7

Spassov N, Acosta-Pankov I (2019) Dispersal history of the golden jackal (Canis aureus moreoticus Geoffroy, 1835) in Europe and possible causes of its recent population explosion. Biodivers Data J 7: e34825. https://doi.org/10.3897/BDJ.7.e34825

Spitzer R, Churski M, Felton A, Heurich M, Kuijper DPJ, Landman M, Rodriguez E, Singh NJ, Taberlet P, van Beeck Calkoen STS, 
Widemo F, Cromsigt JPGM (2019) Doubting dung: eDNA reveals high rates of misidentification in diverse European ungulate communities. Eur J Wildl Res 65(2):28. https://doi.org/10.1007/s10344019-1264-8

Stronen AV, Bartol M, Boljte B et al (2020) "Passive surveillance" across species with cross-amplifying molecular markers: the potential of wolf (Canis lupus) genetic monitoring in tracking golden jackal (C. aureus) colonization and hybridization. Hystrix. https://doi.org/ 10.4404/hystrix-00259-2019

Szabó L, Heltai M, Lanszki J, Szücs E (2007) An indigenous predator, the Golden jackal (Canis aureus L.1758) spreading like an invasive species in Hungary. Bull Univ Agric Sci Vet Maedicine ClujNapoca - Vet Med 64:230-235

Taberlet P, Bouvet J (1994) Mitochondrial DNA polymorphism, phylogeography, and conservation genetics of the brown bear Ursus arctos in Europe. Proc R Soc B Biol Sci 255(1344):195-200

Taberlet P, Luikart G, Waits LP (1999) Noninvasive genetic sampling: look before you leap. Trends Ecol Evol 14(8):323-327

Trouwborst A, Krofel M, Linnell JD (2015) Legal implications of range expansions in a terrestrial carnivore: the case of the golden jackal (Canis aureus) in Europe. Biodivers Conserv 24(10):2593-2610

Vlasseva A, Chassovnikarova T, Atanassov N (2017) Autumn-winter diet and food niche overlap between red fox (Vulpes vulpes L.,
1758) and golden jackal (Canis aureus L., 1758) in two regions in Bulgaria. Acta Zool Bulg 69:217-220

Vynne C, Skalski JR, Machado RB, Groom MJ, Jácomo ATA, MarinhoFilho J, Ramos Neto MB, Pomilla C, Silveira L, Smith H, Wasser SK (2011) Effectiveness of scat detection dogs in determining species presence in a tropical Savana landscape. Conserv Biol 25(1): $154-162$

Wasser SK, Davenport B, Ramage ER, Hunt KE, Parker M, Clarke C, Stenhouse G (2004) Scat detection dogs in wildlife research and management: application to grizzly and black bears in the Yellowhead Ecosystem, Alberta, Canada. Can J Zool 82(3):475492

Webbon CC, Baker PJ, Harris S (2004) Faecal density counts for monitoring changes in red fox numbers in rural Britain. J Appl Ecol 41(4):768-779

Zachos F, Ćirović D, Kirschning J, Otto M, Hartl G, Löscher B-S, Honnen A-C (2009) Genetic variability, differentiation, and founder effect in golden jackals (Canis aureus) from Serbia as revealed by mitochondrial DNA and nuclear microsatellite loci. Biochem Genet 47(3-4):241-250. https://doi.org/10.1007/s10528-009-9221-y

Publisher's note Springer Nature remains neutral with regard to jurisdictional claims in published maps and institutional affiliations. 